\title{
ON MAKING JUDGES DO THE RIGHT THING
}

\section{THOMAS O. MCGARITY $\dagger$}

Professors Shapiro and Levy posit that Chevron ${ }^{1}$ and State Farm, ${ }^{2}$ though frequently cited as landmarks of administrative law, are in reality dead letters. They propose to explain this startling development by juxtaposing the "craft" and "outcome" components of judicial decisionmaking against one another. ${ }^{3}$ Through this simple modeling exercise, they conclude that existing indeterminate craft norms allow judges to achieve desired substantive outcomes when private parties seek judicial review of administrative rulenraking. ${ }^{4}$ Imphicit in this conclusion is the suggestion that judges usually (or at least sometimes) desire to reach particular substantive outcomes in a inore-or-less unprincipled fashion. The authors suggest legislation that would require the courts to toe the line by forcing them to respond to a series of specific questions when they engage in statutory and substantive judicial review. ${ }^{5}$

The heart of Shapiro and Levy's comment is an ambitious attempt to apply "public choice" theory to judicial behavior. Although I admire the effort as an intellectual exercise, its resulting prescriptions give me pause. My problem is not so much with the application as it is with the theory itself. Having committed themselves to the theory, the authors are led inexorably to a solution that, in iny opimion, has little chance of success in the real world.

Practitioners of public choice theory, in my view, often take a very narrow view of the psychological impulses that motivate people to act or decline to act. Judges no doubt want to be respected in the profession (who does not?), and judges (like most

$\dagger$ W. James Kronzer Chair in Trial and Appellate Advocacy, University of Texas School of Law. (1984).

1. Chevron, U.S.A., Inc. v. Natural Resources Defense Council, Inc., 467 U.S. 837 (1983).

2. Motor Vehicle Mfrs. Ass'n v. State Farm Mut. Auto. Ins. Co., 463 U.S. 29

3. Sidney A. Shapiro \& Richard E. Levy, Judicial Incentives and Indeterminacy in Substantive Review of Administrative Decisions, 44 DUKE L.J. 1049, 1060-70 (1995).

4. Id. at 1061.

5. Id. at 1070 . 
public-spirited citizens) desire to live in a good society. Unquestionably, some measure of "goodness" inust derive from judges' personal ideological perspectives. Many judges, after all, are selected precisely because of their commitment to particular ideologies. But it seems overly simplistic to posit a three-dimensional world in whicl a judge engaged in writing an administrative law opinion finds lierself balancing personal ideology against lier desire for respect and lier need for leisure time. Surely, at least some judges feel an obligation to do the job right witlout inucli regard for the respect "payoff." And some judges who do the job wrong may lack for respect among their colleagues, but receive the adoration of fellow ideologues in the political world that they care about.

The authors come to the unsurprising conclusion that judges are more likely to pursue ideological outcomes in areas in which craft norms are indeterminate, and that some judges are inore likely to feel constrained by craft norms than otliers. ${ }^{6}$ I am not sure whether it is craft norms or a broader concern for the legitimacy of the institution that constrains ideological judges from pursumg ideological outcomes, but I certainly concede that most federal appellate judges feel somewhat constrained not to secondguess agencies and legislatures. In any event, Shapiro and Levy very persuasively argue that the indeterminacy of craft norms in admimistrative law gives reviewing judges a great deal of leeway to seek substantive outcomes without loss of imdividual respect.

The more appropriate imquiry is whether judges can seek substantive outcomes without undermining the respect of outsiders for the institution of the federal judiciary. Even if administrative law scloolars can cone up with determinate craft norms and even if judges write ligh-quality opimions when measured against those norms, the institution is still in danger if the end product frustrates the implementation of legislative and executive policies. The losers on judicial review of an expensive multiyear rulemaking initiative are not going to pay mucl attention to wliat other judges (or administrative law scliolars) thimk about the court's fidelity to previously articulated craft norms. If they think the court overstepped its appropriate institutional bounds, they will attack the nistitution, not the opinion writer.

6. Id. at 1077-78. 
The authors next argue that judges (apparently consciously) have achieved a degree of indeterminacy in craft norms through the use of open-ended "standards" of deference and by creating manipulable categories to which different degrees of deference apply. ${ }^{7}$ Thus, the State Farm and Chevron doctrines, though much quoted in the lower courts and in casebooks and law reviews, are in reality elaborate Trojan horses designed to disguise judicial aggrandizement.

Shapiro and Levy are certainly correct in maintaming that the State Farm test for the scope of review of the substance of agency decisions is indeterminate and that the Chevron categories for determining the scope of judicial review of statutory interpretation are very fuzzy. The explanation for these doctrines may be that the judges who crafted the opinions preferred a legal world in which judges are free to ensure substantive outcomes without concern for the loss of personal respect that miglit otherwise result from deviating from clearly articulated standards or categories. Another explanation, however, might be that judges, like legislators, are constrained by language, and it is very hard to draw clear lines and craft clean categories when one is bound by the limitations of the English language.

Shapiro and Levy rely on a substantial body of scholarly inquiry to support their conclusion that the Supreme Court and the lower courts have not felt constrained by craft norms in the area of statutory interpretation, ${ }^{8}$ but they cite little authority for their similar contention in the context of substantive judicial review. This lack of authority is not surprising, because it is very difficult for an observer to tell whether the court in a particular case carefully applied one of the four tests articulated in State Farm $^{9}$ to the record and agency reasoning before the court to conclude that a remand was necessary or rather worked backwards to explain (in what might be higlly deferential language) a predetermined conclusion that the agency's substantive decision had to be set aside. It is equally difficult to tell whether, when a court declines to overturn a rule, it is doing so because it has carefully concluded that the agency's reasoning passes the four tests on the record before the court or because it has simply found the results to be

7. Id. at $1062-63$.

8. Id. at 1051 n.6.

9. 463 U.S. 29 (1983). 
agreeable. This mability of outsiders to read judicial states of mind has implications for efforts to articulate craft norms in legislation.

Shapiro and Levy may be correct in suggesting that as long as judges define the degree of determinacy, they will seek to reduce the cost of pursuing substantive outcomes by relying on indeterminate standards of review. ${ }^{10}$ But it does not necessarily follow that Congress is capable of articulating more determinate standards for the scope of review. The Adiministrative Procedure Act is, after all, a statute that itself inust be interpreted by the courts pursuant to sonie craft norm or anotlier. Nevertheless, Shapiro and Levy should be commended for suggesting actual statutory language and thereby opening up a dialogue on the issue.

Proposed section $706(2)(C),{ }^{11}$ in my opinion, succeeds in conveying a very strong message that courts should not overturn agency interpretation of statutes except in rare instances. It would certainly be difficult for a court to say with a straiglit face that an niterpretation different from that of the agency is "unequivocally required by the traditional tools of statutory construction," ${ }^{12}$ given the indeterminacy of the traditional tools. I would wager that no court could conclude that any issue of statutory imterpretation "lias been specifically resolved by legislative history manifesting an unmistakable congressional intent," ${ }^{, 13}$ given the notorious indeterminacy of legislative history. And few interesting issues of statutory interpretation have been "specifically resolved by explicit statutory language."14

This proposed provision clearly restricts outcoine-oriented judicial exercises of statutory interpretation, but it does so only by coming down firmly on one side of the debate over the appropriate institutional role for the courts in interpreting statutes. In virtually all instances, the courts are to defer to the executive branch's version of what an agency statute says. ${ }^{15}$ The craft norm is less equivocal, because (from an institutional perspective) it is virtually absolute.

\footnotetext{
10. Shapiro \& Levy, supra note 3, at 1069.

11. Id. at 1071-72.

12. Id. (proposed $\S 706(2)(C)(3))$.

13. Id. (proposed \& 706(2)(C)(2)).

14. Id. (proposed $\& 706(2)(C)(1))$.

15. See id. (proposed $\S 706(2)(C)$ ).
} 
It is possible (and these days even probable) that Congress might want to resolve the institutional question differently. Congress might determine that courts should be less deferential to executive branch interpretations of statutes without going to the extreme of providing for de novo judicial resolution of questions of statutory interpretation. If Congress takes this intermediate position on the question of the degree of deference that courts should accord to agency interpretation of statutes, what language would it use in section 706 to provide a clearly articulated craft norm? I invite Professors Shapiro and Levy to take a stab at drafting language that impleinents a less-than-absolutist position on the institutional question.

The authors' attempt to articulate clear craft norms for the substantive judicial review function in subsections (D) and (E) of proposed section $706^{16}$ is, in my opinion, much less successful. It may be easy enough, when the agency is honest about the reasons for its decisions, to determine that an agency relied on policy concerns that were precluded by its statute; sometimes "smoking gun" ineinos reveal what "really" motivated the agency. But a court would probably find it difficult to ascertain objectively whetler an agency has "entirely failed to consider an important aspect of the problem." 17 Applying this craft norm necessarily would require judicial discretion on critical aspects of the inquiry, such as whether an aspect of the problem identified by the parties is "important" or not and whether an agency that paid lip service to an aspect of the problem "entirely failed to consider" that aspect. The "record evidence" imquiry specified in subsection $(E)^{18}$ also leaves much room for judicial discretion. How would a court measure whether an explanation is "logically colserent" in the not infrequently encountered context of bits and pieces of objective data swirling in a sea of uncertainty? Indeterminacy, alas, comes in many shapes and sizes.

In sum, although I commend Professors Shapiro and Levy for their willingness to offer concrete solutions to the very real problem of judicial overreaching in reviewing admimistrative rulemaking, I am not nearly as sanguine as they are about the poten-

16. Id. at 1072-73.

17. Id. at 1072 .

18. Id. 
tial for statutory language to influence judicial behavior. Perhaps another solution is for law professors to spend more time challenging the reputations of judges who too vigorously pursue personal outcome norms. If judges are truly concerned about how others view them, then the prospect of a scathing law review article should make an activist judge think twice about intruding too deeply into the substance of admimistrative decisionmaking. This suggestion, however, assumes (incorrectly, I fear) that judges read law review articles and care what law professors think about thein. 